\section{Comparative anatomy of leaves of Kalanchoe pinnata and $K$. crenata in sun and shade conditions, as a support for their identification}

\author{
Nattacha S. Moreira, ${ }^{1}$ Luana Beatriz S. Nascimento, ${ }^{1}$ Marcos \\ Vinicius Leal-Costa, ${ }^{3}$ Eliana S. Tavares ${ }^{*}, 1,2$
}

${ }^{1}$ Laboratório de Anatomia Vegetal, Departamento de Botânica, Instituto de Biologia, Universidade Federal do Rio de Janeiro, Brazil,

${ }^{2}$ Programa de Pós-graduação em Biotecnologia Vegetal, Centro de Ciências da Saúde, Universidade Federal do Rio de Janeiro, Brazil,

${ }^{3}$ Instituto Federal de Educação, Ciência e Tecnologia Fluminense, Campus Centro, Brazil.
Revista Brasileira de Farmacognosia Brazilian Journal of Pharmacognosy

\begin{abstract}
Kalanchoe pinnata (Lam.) Pers. and K. crenata (Andrews) Haw., Crassulaceae, are popularly used in the treatment of many diseases. Their biological activities, such as anti-leishmaniasis and analgesic, can be useful in phytotherapy. Both species are often misidentified as the other, because of their similar popular uses and names, and the similar external morphology of the leaves. We investigated the existence of anatomical characters that will permit correct identification of the species grown in shade and in sun conditions. We also contribute with new observations on the leaf anatomy of $K$. pinnata and $K$. crenata. Fixed $\left(\mathrm{FAA}_{70}\right.$ ) leaves were used, and their sections were embedded in Leica historesin. Hydathodes were observed in both species, and for the first time were anatomically described in $K$. crenata. The species showed anatomical differences in relation to the presence of epidermal idioblasts only in $K$. crenata, the different pattern of distribution of subepidermal idioblasts, and the presence of leaf buds only in K. pinnata.
\end{abstract} 22(5): 929-936, Sep./Oct. 2012

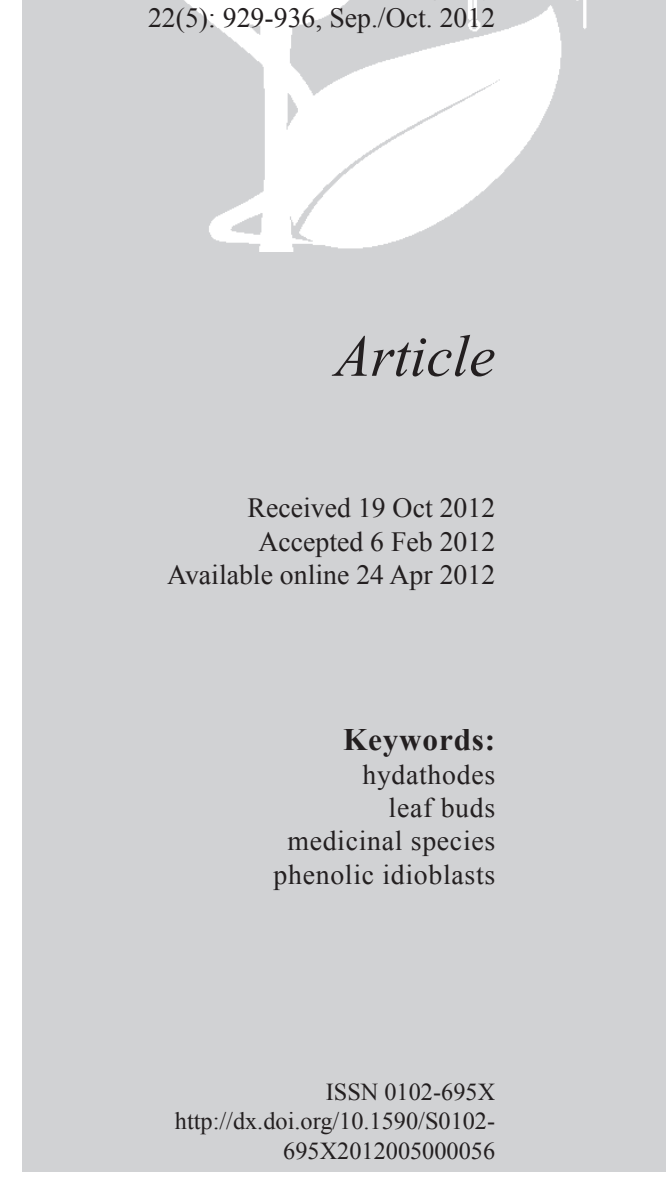

Received 19 Oct 2012 Accepted 6 Feb 2012 Available online 24 Apr 2012

\section{Introduction}

The species of Crassulaceae are Crassulacean Acid Metabolism (CAM) plants. Unlike $\mathrm{C}_{3}$ and $\mathrm{C}_{4}$ plants, CAM plants assimilate atmospheric $\mathrm{CO}_{2}$ into $\mathrm{C} 4$ acids at night, and subsequently fix this $\mathrm{CO}_{2}$ to the carbohydrate level during the following day (Cushman \& Bohnert, 1997).

Two species of this family, Kalanchoe pinnata (Lam.) Pers. and K. crenata (Andrews) Haw., are popularly used to treat several diseases, including bronchitis and gastritis (Moreira, et al. 2002; Medeiros et al. 2004; Silva et al., 2006). Besides their common uses, these species share characteristics related to leaf morphology, including decussate, succulent, and glabrous leaves; ovate to elliptical leaf blades; and crenate margins (Hyakutake \& Grotta, 1972; Anjoo \& Kumar, 2010). Although $K$. crenata has simple leaves and $K$. pinnata has simple or compound ones, their leaves are very similar, especially when $K$. pinnata has only simple leaves. Because of their similarities, both species are known in Brazil as folha-dacosta, saião, and coirama (Brito \& Brito, 1993; Medeiros et al. 2004; Silva et al., 2006; Joseph et al., 2011).
Several biological activities have been reported for $K$. pinnata and $K$. crenata, including antileishmaniasis (Muzitano et al., 2006), antinociceptive, anti-inflammatory, and antidiabetic (Ojewole, 2005) for K. pinnata, and analgesic and anticonvulsant (Nguelefack et al., 2006) for $K$. crenata. In both species, the leaf is the plant organ that is most used in folk medicine and in studies of biological activity.

Leaves are highly susceptible to environmental variations, mainly light intensity. Leaves developed under high light (sun leaves) are usually smaller and thicker, frequently have a higher density of stomata, a thicker epidermis and cuticle, and more developed mesophyll compared to leaves developed under low light (shade leaves) (Dickison, 2000; Schulze et al., 2002).

Knowledge of leaf anatomy is essential for the registration and quality control of herbal medicines (Anvisa RDC No. 48/2004). Plants used in herbal medicines may be subject to different degrees of shading during growth. Therefore, studies of medicinal plants grown under different light conditions are important to examine photomorphogenic changes that may cause problems with their identification (Milaneze-Gutierre et 
al., 2003).

Some anatomical studies have examined K. pinnata (Jain et al. 2008; Anjoo \& Kumar, 2010; Leal-Costa et al. 2010) and K. crenata (Hyakutake \& Grotta, 1972). However, these studies provided neither information about the influence of environmental light intensity on the leaf anatomy of these species, nor a detailed anatomical description of them. Therefore, in view of the potential for development of herbal medicines from $K$. pinnata and $K$. crenata leaves, and considering the difficulties in differentiating between them based on their external morphology during the vegetative stage, this study aimed to contribute to their anatomical description and to highlight distinguishing characters that are stable in different light conditions.

\section{Material and Methods}

\section{Plant material}

Specimens of Kalanchoe pinnata (Lam.) Pers. and $K$. crenata (Andrews) Haw., Crassulaceae, were obtained from the Botanical Garden of Rio de Janeiro. The voucher specimens were deposited at the Universidade Federal do Rio de Janeiro Herbarium (RFA37525 and RFA37524, respectively).

\section{Cultivation conditions}

Young plants (4-5 months) were obtained from the Botanical Garden of Rio de Janeiro. Six specimens of each species were planted in individual hard plastic pots, with the same substrate and watering routine. Three plants of each species were grown in sun and three in shade (under a tree). Photosynthetically active radiation (PAR) was measured monthly during the course of a year, on sunny days, with a PAR sensor coupled to an FMS2 Hansatech fluorometer (Hansatech Instruments Ltd., King's Lynn, UK). The PAR intensity ranged from 413.9 to $801.3 \mu \mathrm{mol} \mathrm{m}^{-2} \mathrm{~s}^{-1}$ for the sun plants, and from 12.8 to $19.9 \mu \mathrm{mol} \mathrm{m}^{-2} \mathrm{~s}^{-1}$ for the shade plants.

\section{Leaf anatomy}

Three simple leaves from the fourth node of

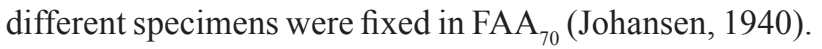
Leaf fragments were embedded in Leica Historesin ${ }^{\circledR}$ and sectioned in a Spencer rotary microtome. Cross sections were made in the proximal, middle, and distal regions of the petiole, and in the base, middle-third and apex of the leaf blade. The sections were stained with toluidine blue and mounted in Entellan ${ }^{\circledR}$. Paradermal sections were cut mechanically and the fragments were stained in hydroalcoholic safranin (Johansen, 1940). Microchemical tests were performed on fresh material:
Sudan III to reveal lipids (Sass, 1951), lugol for starch (Johansen, 1940), Coomassie brilliant blue for protein (Fisher, 1968), and potassium dichromate for phenolic compounds (Gabe, 1968). Measurements of epidermis and mesophyll thickness, number of vascular bundles over $1 \mathrm{~mm}$, and stomatal density were made in the middle third of fourth-node leaves with an optical microscope (Zeiss Standard) equipped with a drawing tube. Three repetitions of ten measurements were made on leaves of different specimens. Statistical analysis was performed by the GraphPad Instat 3.0 for Windows ${ }^{\circledR}$ program, using the $t$ test $(p<0.05)$. The photographs were taken by means of an Olympus $\mathrm{CH} 30$ light microscope with an attached Olympus PM-C35B camera.

\section{Results and Discussion}

Morphological differences between sun and shade plants

Kalanchoe pinnata (Lam.) Pers. and K. crenata (Andrews) Haw., Crassulaceae, plants grown in sun were taller, although sun plants are usually taller when grown in shade (Taiz \& Zeiger, 2009). In both species, the sun plants had larger and thicker leaves than the shade ones (Figure 1). This result differs from observations reported for sun leaves regarding leaf size, which are generally smaller, but not for leaf thickness (Esau, 1974). Kalanchoe crenata showed rounded leaves with slightly crenate margins in shade conditions, and elliptical leaves with pronounced crenate margins in sun conditions. K. pinnata showed a purple coloration on the petiole and leaf blade margins only in sun conditions (Figure 1).

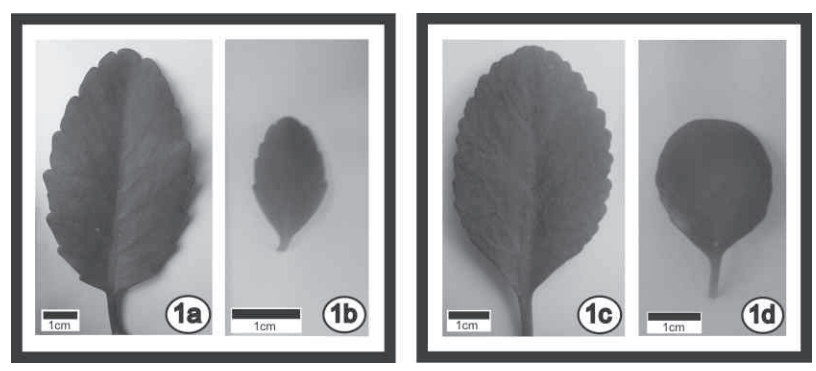

Figure 1. Kalanchoe pinnata grown under sun (1a) and shade (1b); Kalanchoe crenata grown under sun (1c) and shade (1d).

The plant height may have different patterns of response according to the species' adaptive capacity to changes in light intensity (Muroya et al., 1997). Responses in leaf size may also differ between shade-tolerant and intolerant species (Evans \& Hughes, 1961; Dengler, 1980; Dale, 1988).

\section{Leaf anatomy}

In $K$. pinnata epidermis, the anticlinal walls were sinuous on both sides, but the sinuosity was more 
pronounced on the adaxial surface (Figure 2a) than on the abaxial one, in sun leaves (Figure 2b). In $K$. crenata sun leaves, the anticlinal walls were straight to slightly sinuous on the adaxial surface (Figure 3a) and sinuous on the abaxial surface (Figure 3b). In shade leaves of both species, the degree of sinuosity was the same on both surfaces (Figures 2c-d, 3c-d).

Both species are amphistomatic with anisocytic stomata (Figures 2c, 3a). This state has also been reported for other species of Crassulaceae (Duarte \& Zaneti, 2002; Chernetskyy \& Weryszko-Chmielewska, 2008).

Kalanchoe pinnata and $K$. crenata have fully formed functional stomata, as well as others that are still differentiating (Figures 2d, 3b). The same trait was observed in Kalanchoe pumila by Chernetskyy \& Weryszko-Chmielewska (2008), and is related to the ability of leaves of succulents to undergo cell division long after the leaves are photosynthetically active (Ting \& Gibbs, 1982).

In both species and cultivation conditions, the abaxial surface had more stomata than the adaxial one. The stomatal density was lower in shade plants (Table 1). Jain et al. (2008) found a stomatal density of $18-20$ stomata $/ \mathrm{mm}^{2}$ in $K$. pinnata, but the light conditions were not described. According to Ting \& Gibbs (1982), CAM plants commonly have stomatal densities varying from 10 to $65 \mathrm{~mm}^{-2}$, as found in this study.

In both species, the epidermis in cross-section
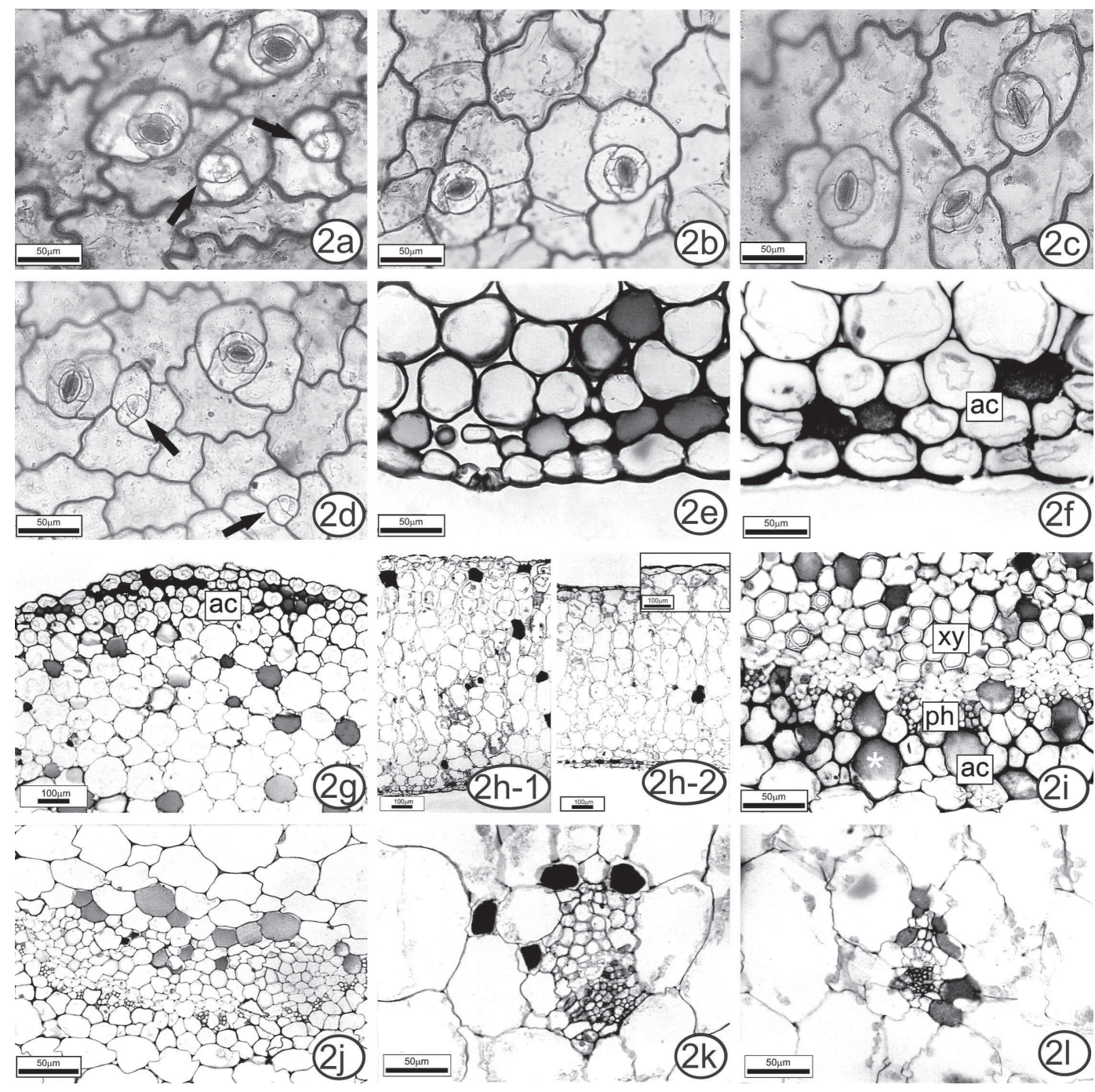

Figure 2. Aspects of the leaf anatomy of Kalanchoe pinnata grown in sun and shade. Paradermal sections: intercostal region of blade (a-b) in sun leaves; (c-d) in shade leaves. Anisocytic stomata on both surfaces and in different levels of differentiation ( $\mathrm{a}, \mathrm{d}$ - arrows). Cross sections of petiole $(\mathrm{e}, \mathrm{g})$ and blade ( $\mathrm{f}, \mathrm{h}-1)$ : angular collenchyma in subepidermal position (f-g). Homogeneous mesophyll in sun plants (h-1) and shade plants (h-2). Collateral vascular bundles (i-l) more developed in sun plants $(\mathrm{i}, \mathrm{k})$ than in shade plants $(\mathrm{j}, 1)$. Phenolic idioblasts $\left({ }^{*}\right)$. Legend: ac: angular collenchyma; xy: xylem; ph: phloem. 

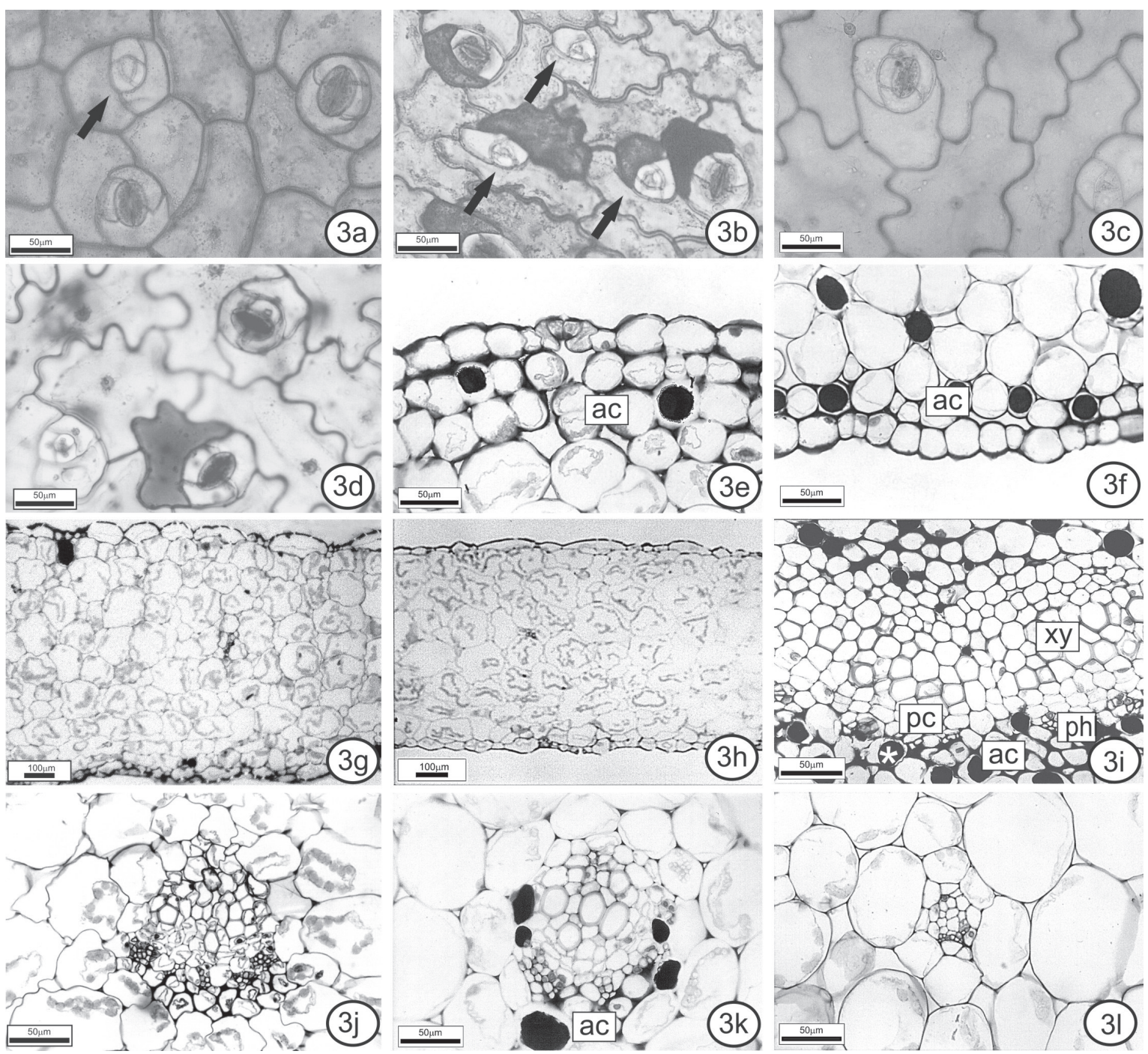

Figure 3. Aspects of the leaf anatomy of Kalanchoe crenata grown in sun and shade. Paradermal sections: intercostal region of blade (a-b) in sun leaves; (c-d) in shade leaves. Anisocytic stomata occur on both surfaces and in different levels of differentiation (a,b - arrows). Cross sections of petiole (e) and blade (f-l): angular collenchyma in the subepidermal position (e-f). Homogeneous mesophyll in sun plants (g) and shade plants (h). Collateral vascular bundles (i-l) more developed in sun plants (i,k) than in shade plants ( $\mathrm{j}, \mathrm{l})$. Phenolic idioblasts*. Legend: ac: angular collenchyma; xy: xylem; ph: phloem.

Table 1. Comparison of anatomical characters of Kalanchoe pinnata and Kalanchoe crenata sun and shade plants.

\begin{tabular}{lcccccc}
\hline & \multicolumn{2}{c}{ Stomatal density $\left(\right.$ stomata $\left.\mathrm{mm}^{-2}\right)$} & \multicolumn{2}{c}{ Thickness of epidermis $(\mu \mathrm{m})$} & \multicolumn{2}{c}{ Thickness of } \\
\cline { 2 - 5 } & Adaxial surface & Abaxial surface & Adaxial surface & Abaxial surface & $\begin{array}{c}\text { Number of } \\
\text { mesophll }(\mu \mathrm{m})\end{array}$ & vascular bundles \\
\hline K. pinnata Sun & $23.33 \pm 2.78^{\mathrm{A}, \mathrm{a}}$ & $56.63 \pm 6.67^{\mathrm{B}, \mathrm{a}}$ & $37.23 \pm 6.57^{\mathrm{A}, \mathrm{a}}$ & $28.47 \pm 6.57^{\mathrm{B}, \mathrm{a}}$ & $1264.23 \pm 21.8^{\mathrm{a}}$ & $1.77 \pm 0.63^{\mathrm{a}}$ \\
K. pinnata Shade & $17.80 \pm 5.06^{\mathrm{A}, \mathrm{b}}$ & $40.93 \pm 5.17^{\mathrm{B}, \mathrm{b}}$ & $29.93 \pm 5.84^{\mathrm{A}, \mathrm{b}}$ & $24.09 \pm 7.30^{\mathrm{B}, \mathrm{b}}$ & $766.42 \pm 78.10^{\mathrm{b}}$ & $1.43 \pm 0.57^{\mathrm{b}}$ \\
K. crenata Sun & $23.93 \pm 7.25^{\mathrm{A}, \mathrm{a}}$ & $41.16 \pm 6.64^{\mathrm{B}, \mathrm{a}}$ & $39.41 \pm 13.14^{\mathrm{A}, \mathrm{a}}$ & $28.47 \pm 8.76^{\mathrm{B}, \mathrm{b}}$ & $686.13 \pm 58.39^{\mathrm{a}}$ & $1.70 \pm 0.70^{\mathrm{a}}$ \\
K. crenata Shade & $15.70 \pm 3.97^{\mathrm{A}, \mathrm{b}}$ & $30.63 \pm 8.22^{\mathrm{B}, \mathrm{b}}$ & $38.67 \pm 9.49^{\mathrm{A}, \mathrm{a}}$ & $28.47 \pm 7.30^{\mathrm{B}, \mathrm{b}}$ & $577.37 \pm 42.34^{\mathrm{b}}$ & $1.30 \pm 0.50^{\mathrm{b}}$ \\
\hline
\end{tabular}

*Different letters indicate significantly different values $(p \leq 0.05, \mathrm{n}=3)$. For each parameter, capital letters indicate a comparison of values between the adaxial and abaxial surfaces; lower-case letters indicate a comparison between the values of sun and shade plants. 
was uniseriate, with stomata at the same or slightly above the level of other epidermal cells (Figures 2e, 3e). These characteristics are shared by other crassulaceans (Duarte \& Zaneti, 2002; Chernetskyy \& Weryszko-Chmielewska, 2008), except Kalanchoe daigrementiana, which has one to three epidermal cell layers (Balsamo \& Uribe, 1988).

Epidermal cells of the petiole varied little in shape and size (Figures 2e, 3e). In the leaf blade, the cells were more rounded in the midrib (Figures 2f, 3f), and rectangular-flat in the intercostal region (Figures $2 \mathrm{~h}$, $3 \mathrm{~g}$-h). The epidermal cells of the leaf margin were larger than in the other regions (Figures $4 \mathrm{a}, \mathrm{c}$ ). The epidermis was covered by a thin cuticle.

$K$. pinnata sun plants had a thicker epidermis than shade plants (Table 1), a feature generally described (Schulze et al., 2002). Kalanchoe crenata sun and shade plants did not show significant differences in epidermal thickness (Table 1). In both species and both cultivation conditions, the epidermal cells were thicker on the adaxial surface.

In both species, sun plants had some angular collenchyma layers in the subepidermal position, in the petiole (Figures. 2g, 3e), and in the blade midrib (Figures 2f, 3f). In shade plants, this tissue was less developed, with a more restricted distribution. Below the collenchyma, some chlorenchyma layers followed by ground parenchyma occurred.

The mesophyll in both species was homogeneous

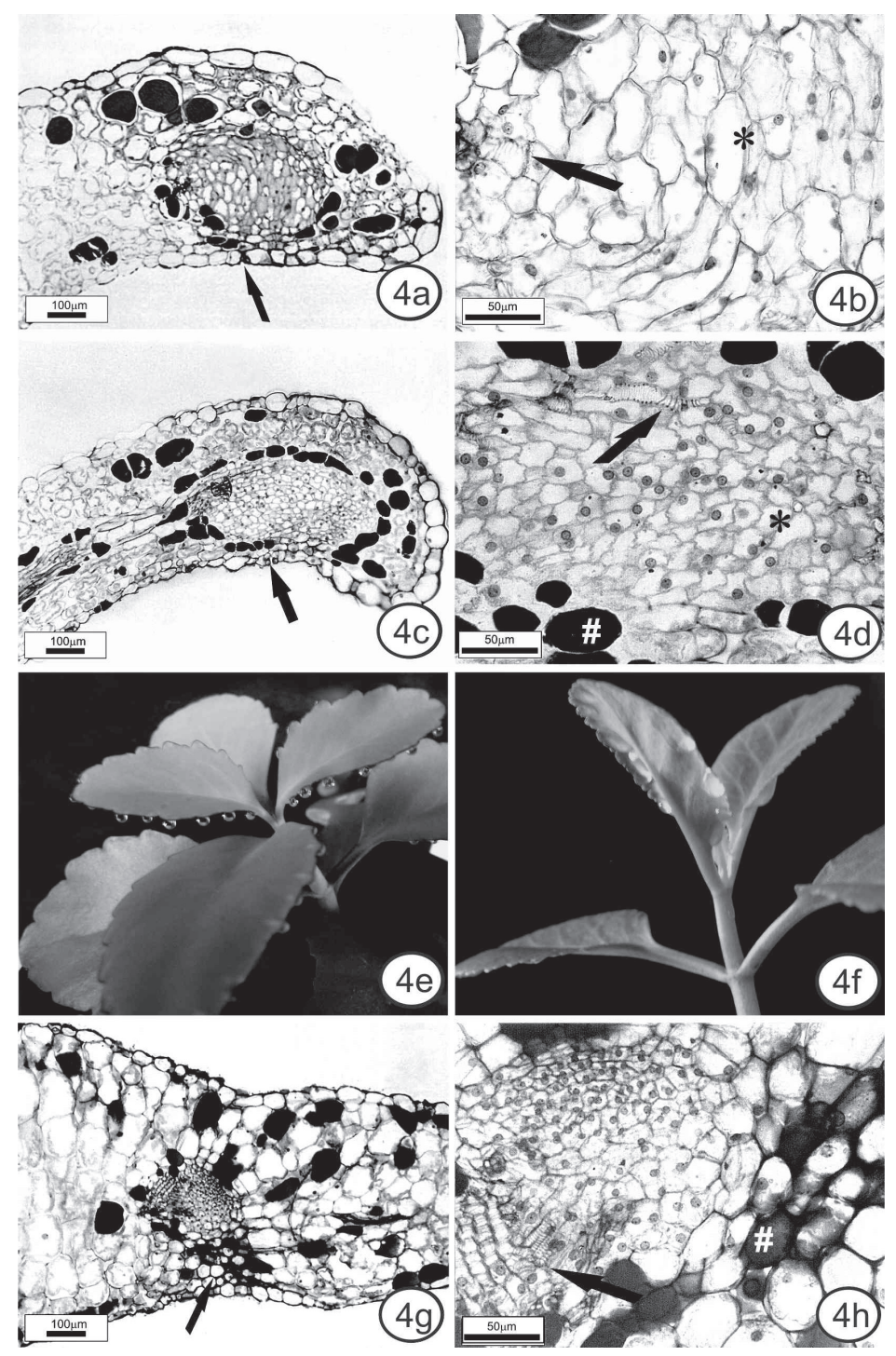

Figure 4. Anatomical aspects of the hydathodes and buds. Leaf cross sections of the hydathodes in $K$. pinnata $(\mathrm{a}, \mathrm{b})$ and $K$. crenata (c,d). Tracheids (b,d - arrows) reaching the epithem (*), and a stoma located on the abaxial side (a,c - arrows). Guttation under experimental conditions in $K$. pinnata (e) and $K$. crenata (f). Leaf cross sections of the structure of the buds in K. pinnata (g,h). Bud cells protected by collenchyma on the abaxial surface (g - arrow). Vascular bundle associated with the bud (h - arrow). Phenolic idioblasts (\#) are related to hydathodes (d) and buds (h). 
and the mesophyll thickness was significantly greater in sun plants (Table 1), because of a larger number of chlorenchyma layers (Figures 2h, 3g-h). The species shared some features that are commonly found in CAM species: succulent leaves, thick mesophyll with large cells with large vacuoles, and relatively small intercellular spaces (Nelson et al., 2005).

$K$. pinnata and $K$. crenata had collateral vascular bundles (Figures 2i-1, 3i-1), as observed for other crassulaceans (Duarte \& Zaneti, 2002; Chernetskyy \& Weryszko-Chmielewska, 2008). In the petiole and leaf midrib, the main vascular bundles had adjacent angular collenchyma (Figures 2i-j, 3i-j). Small vascular bundles frequently had associated angular collenchyma in sun plants (Figure $3 \mathrm{k}$ ). In shade plants, the vascular bundles were fewer (Table 1) and less developed (Figures 21, 31).

Hydathodes were observed in leaf blade margins in both species. In cross-section, they are delimited by a sheath (Figures $4 \mathrm{a}, \mathrm{c}$ ). The epithem is composed of various shapes and sizes of cells in $K$. pinnata and generally isodiametric cells in $K$. crenata, without obvious intercellular spaces (Figures 4b, d). Nuclei can be seen by light microscopy. Tracheids are seen between epithem cells (Figure 4b, d). A stoma is located on the abaxial

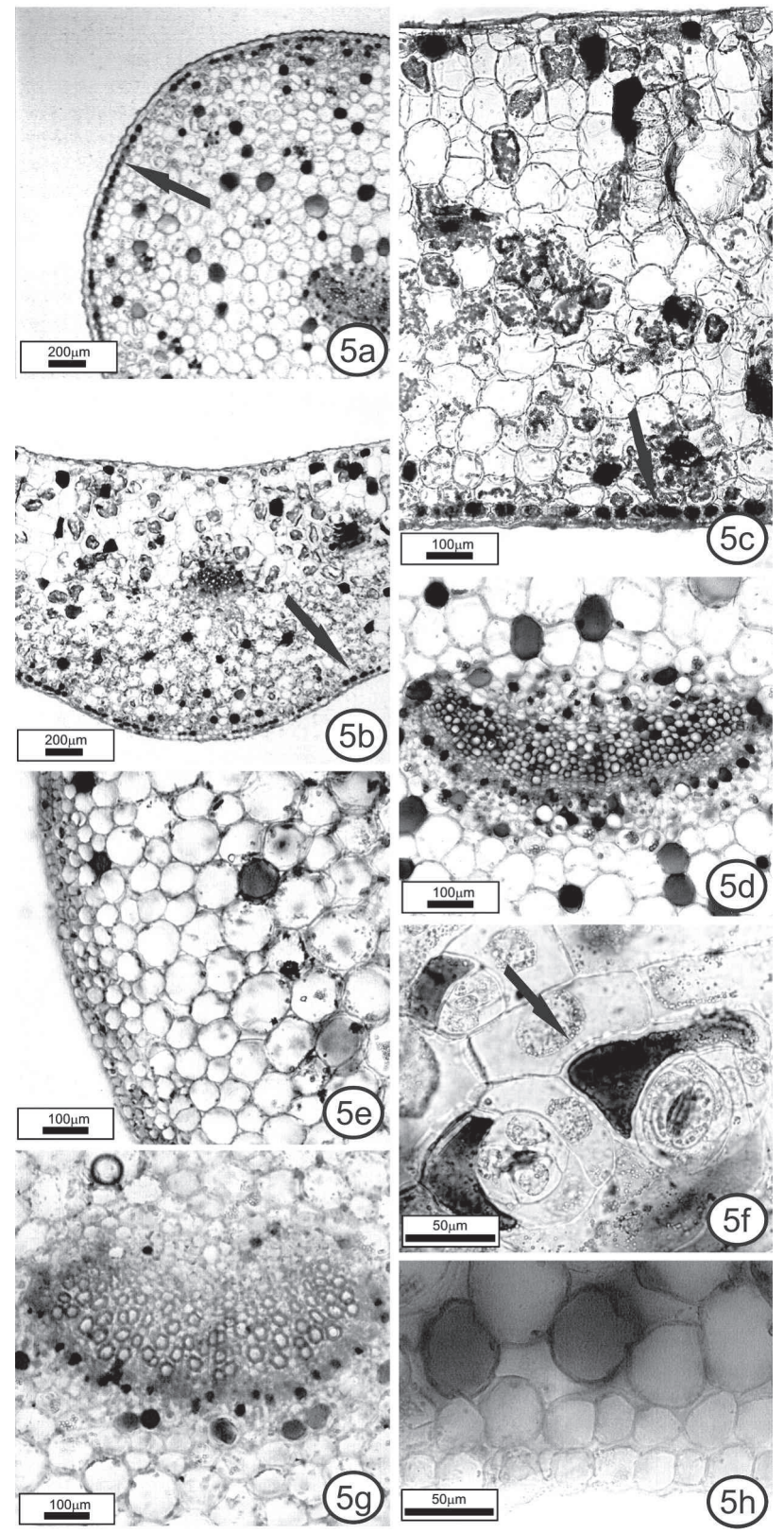

Figure 5. Microchemical test. Phenolic idioblasts in $K$. pinnata (a-d) and K. crenata (e-h). Idioblasts in the petiole (a,e,g) and leaf blade (b,c,d,f,h). In $K$. pinnata, the idioblast subepidermal layer can be observed, mainly in the petiole (a - arrow) and the midrib (b - arrow). In the midrib and the intercostal region (c), idioblasts were more numerous near the abaxial side. Only K. crenata showed idioblasts in the epidermis in the intercostal region ( $\mathrm{f}$ - arrow). 
surface (Figure 4a, c).

The hydathodes of $K$. pinnata and $K$. crenata differ from hydathodes of other families in having few intercellular spaces between epithem cells. There are no reports of hydathodes for the other species of Kalanchoe. The hydathodes are often related to guttation, and this phenomemon was observed in $K$. pinnata and $K$. crenata in experimental conditions (glass cover - Figure 4e, f).

The buds of $K$. pinnata are located in the deeper recesses of the leaf margin. They contain small meristem cells with visible nuclei and more differentiated isodiametric cells, some of them without an obvious nucleus. These cells are protected by collenchyma on the abaxial side (Figure 4g). There is also a vascular bundle associated with the bud (Figure 4h). According to Yarbrough (1932), as the leaf expands there is a tendency for a small group of marginal meristem cells to be set off or left behind in the development of the notch.

\section{Microchemical tests}

Phenolic idioblasts, revealed by the potassium dichromate and toluidine blue dye, were found along the entire petiole (Figure 5a, e, g) and leaf blade (Figure 5b-d, $\mathrm{f}, \mathrm{h}$ ), including close to hydathodes (Figure $4 \mathrm{~d}$ ) and buds (Figure 4h), in sun and shade K. pinnata and $K$. crenata plants.

$K$. pinnata contains large numbers of phenolic idioblasts in the subepidermal position, forming a layer in many regions, except at the leaf margin. The layers were observed mainly in the petiole (Figure 5a) and in the midrib (Figure 5b); in the midrib and in the intercostal region (Figure 5c), the idioblasts were more numerous near the abaxial side. A similar pattern of distribution was found in K. pumila (Chernetskyy \& Weryszko-Chmielewska, 2008). In $K$. crenata, the subepidermal idioblasts occurred isolated or together, but never forming a layer. Only $K$. crenata had idioblasts in the epidermis, in the intercostal region. They were more numerous on the abaxial surface (Figure 5f).

In shade plants of both species, the idioblasts showed the same pattern as sun plants, although they were less frequent. In a previous study, the production of phenolic compounds increased in K. pinnata grown in vitro under supplemental blue light (Leal-Costa et al., 2010).

\section{Conclusion}

In spite of the anatomical similarities of these species, differences were observed in the pattern of distribution of subepidermal idioblasts, which were isolated or grouped in $K$. crenata, but never formed layers as in $K$. pinnata; the occurrence of idioblasts in the epidermis only in $K$. crenata; and the presence of buds only on the $K$. pinnata leaf margin. These differences remained constant under different lighting conditions. Therefore, they can aid in anatomy-level identification of the species and consequently in quality control of $K$. pinnata and $K$. crenata herbal medicines.

\section{Acknowledgements}

The authors express their gratitude to Ms. Yara Lucia Oliveira de Britto, Rio de Janeiro Botanical Garden, for her contribution to this study; and to Janet W. Reid for English revision. This work was supported by the Fundação de Amparo à Pesquisa do Estado do Rio de Janeiro and the Coordenação de Aperfeiçoamento de Pessoal de Nível Superior.

\section{References}

Anjoo K, Kumar SA 2010. Microscopical and preliminary phytochemical studies on aerial part (leaves and stem) of Bryophyllum pinnatum Kurz. Phcog J 2: 254-259.

Balsamo RA, Uribe EG 1988. Leaf anatomy and ultrastructure of the Crassulacean-acid-metabolism plant Kalanchoe daigremontiana. Planta 173: 183-189.

Brito ARMS, Brito AAS 1993. Forty years of Brazilian medicinal plant research. J Ethnopharmacol 39: 53-67.

Chernetskyy M, Weryszko-Chmielewska E 2008. Structure of Kalanchoe pumila Bak. leaves (Crassulaceae DC.). Acta Agrobot 61: 11-24.

Cushman JC, Bohnert HJ 1997. Molecular genetics of Crassulacean acid metabolism. Plant Physiol 113: 66676676.

Dale JE 1988. The control of leaf expansion. Ann Rev Plant Physiol Plant Mol Biol 39: 267-295.

Dengler NG 1980. Comparative histological basis of sun and shade leaf dimorphism in Helianthus annuus. Can J Bot 58: 717-730.

Dickison WC 2000. Integrative Plant Anatomy. San Diego: Academic Press.

Duarte MR, Zaneti CC 2002. Morfologia de folhas de bálsamo: Sedum dendroideum Moc. et Sessé ex DC, Crassulaceae. Rev Lecta 20: 153-160.

Esau K 1974. Anatomia das Plantas com Sementes. São Paulo: Edgard Blucher.

Evans GC, Hughes AP 1961. Plant growth and the aerial environment. I. Effect of artificial shading on Impatiens parviflora DC. New Phytol 60: 158-186.

Fisher DB 1968. Protein staining of ribboned Epon sections for light microscopy. Histochemie 16: 92-96.

Gabe M 1968. Techniques Histologiques. Paris: Masson \& Cie.

Hyakutake S, Grotta AS 1972. Contribuição para o estudo morfológico e anatômico de Kalanchoe brasiliensis Cambressèdes - Crassulaceae. Rev Farm Bioquim Univ São Paulo 10: 217-237.

Jain VC, Shah DP, Patel NM 2008. Microscopical and preliminary 
phytochemical studies on leaves of Bryophyllum calycinum Salisb. J Pharm Res 1: 230-232.

Johansen DA 1940. Plant Microtechnique. New York: McGrawHill Book Co.

Joseph B, Sridhar B, Sankarganesh, Justinraj, Edwin BT 2011. Rare medicinal plant-Kalanchoe pinnata. Res $J$ Microbiol 6: 322-327.

Leal-Costa MV, Nascimento LBS, Moreira NS, Reinert F, Costa SS, Lage CLS, Tavares ES 2010. Influence of blue light on the leaf morphoanatomy of in vitro Kalanchoe pinnata (Lamarck) Persoon (Crassulaceae). Microsc Microanal 16: 576-582.

Medeiros MFT, Fonseca VS, Andreata RHP 2004. Plantas medicinais e seus usos pelos sitiantes da Reserva Rio das Pedras, Magaratiba, RJ, Brasil. Acta Bot Bras 18: 391-399.

Milaneze-Gutierre MA, Mello JCP, Delaporte RH 2003. Efeitos da intensidade luminosa sobre a morfo-anatomia foliar de Bouchea fluminensis. Rev Bras Farmacogn 13: 2333.

Moreira RCT, Costa LCB, Costa RCS, Rocha EA 2002. Abordagem etnobotânica acerca do uso de plantas medicinais na Vila Cachoeira, Ilhéus, Bahia, Brasil. Acta Farm Bonaer 21: 205-211.

Muroya K, Varela VP, Campos MAA 1997. Análise de crescimento de mudas de Jacareúba (Calophyllum angulare A. C. Smith - Gittiferae) cultivadas em condições de viveiro. Acta Amaz 27: 197-212.

Muzitano MF, Tinoco LW, Guette C, Kaiser CR; RossiBergmann B, Costa SS 2006. The antileishmanial activity assessment of unusual flavonoids from Kalanchoe pinnata. Phytochemistry 67: 2071-2077.

Nelson EA, Sage TL, Sage RF 2005. Functional leaf anatomy of plants with crassulacean acid metabolism. Funct Plant Biol 32: 409-419.
Nguelefack TB, Nana P, Atsamo AD, Dimo T, Watcho P, Dongmo AB, Tapondjou LA, Njamen D, Wansi SL, Kamanyi A 2006. Analgesic and anticonvulsant effects of extracts from the leaves of Kalanchoe crenata (Andrews) Haworth (Crassulaceae). J Ethnopharmacol 106: 70-75.

Ojewole JAO 2005. Antinociceptive, anti-inflammatory and antidiabetic effects of Bryophyllum pinnatum (Crassulaceae) leaf aqueous extract. J Ethnopharmacol 99: 13-19.

Sass JE 1951. Botanical Microtechnique. $2^{\text {nd }}$ ed. Ames: The Iowa State College Press.

Schulze ED, Beck E, Müller-Hohenstein K 2002. Plant Ecology. New York: Springer.

Silva MS, Antoniolli AR, Batista JS, Mota CN 2006. Plantas medicinais usadas nos distúrbios do trato gastrintestinal no povoado Colônia Treze, Lagarto, SE, Brasil. Acta Bot Bras 20: 815-829.

Taiz L, Zeiger E 2009. Fisiologia Vegetal. Porto Alegre: Artmed.

Ting IP, Gibbs M 1982. Crassulacean Acid Metabolism. Baltimore: Waverly Press.

Yarbrough JA 1932. Anatomical and developmental studies of the foliar embryos of Bryophyllum calycinum. Am J Bot 19: 443-453.

\section{*Correspondence}

\section{Eliana S. Tavares}

Laboratório de Anatomia Vegetal, Departamento de Botânica, Instituto de Biologia, Universidade Federal do Rio de Janeiro Avenida Professor Rodolpho Paulo Rocco s/n, Ilha do Fundão, 21.941-902 Rio de Janeiro-RJ, Brazil

elianast@biologia.ufrj.br

Tel. +552125626328 